\title{
THE EFFECT OF INSULIN ON NONESTERIFIED FATTY ACID RELEASE FROM THE HUMAN LEG *
}

\author{
By E. H. ESTES, JR., M. D. BOGDONOFF, S. J. FRIEDBERG, $\dagger$ W. R. HARLAN, JR. \\ AND D. L. TROUT
}

\author{
(From the Central Reference Laboratory, Veterans Administration Hospital and the Department \\ of Medicine, Duke University Medical Center, Durham, N. C.)
}

(Submitted for publication June 15, 1959 ; accepted August 3, 1959)

In recent years much interest has been focused on the plasma level of nonesterified fatty acid (NEFA), or unesterified fatty acid (UFA), and on its role as an energy substrate, particularly for muscle and liver.

Both insulin and glucose produce a rapid fall in serum NEFA level $(1,2)$, which is related to a decreased output of NEFA from the adipose cell $(3,4)$. The concept has arisen that in the fasting state NEFA is continuously mobilized from fat stores, and when glucose becomes available, this mobilization ceases and the blood level falls (5).

Several years ago Bell and Burns (6) showed that the intra-arterial injection of small doses of insulin into the leg of a human subject caused a prompt widening of the arteriovenous (A-V) difference for glucose across the injected limb as compared to the opposite noninjected limb. This apparent fixation of the insulin in the injected limb and the resulting differential metabolic effect seemed to offer an opportunity to study further the effect of insulin on NEFA handling by the peripheral tissues.

\section{METHODS}

Studies have been carried out on six normal fasting human subjects. Indwelling Cournand needles were placed in one femoral artery and in both femoral veins under procaine anesthesia. Simultaneous control samples were drawn from each of these three sites, followed by a small dose of glucagon-free insulin (one-half to one unit) injected intra-arterially. Thus insulin was injected directly into one limb, reaching the other limb after at least one circuit and in smaller concentration.

Care was taken to insure simultaneous withdrawal of

* This investigation was supported in part by a research grant from the Life Insurance Medical Research Fund, in part by a research grant H-1217 (C6) from the National Heart Institute, United States Public Health Service, and in part by the Regional Center for the Study of Aging, Duke University.

$\dagger$ Research Fellow, American Heart Association. all samples. Immediately after withdrawal, $5 \mathrm{ml}$. of blood was transferred from each syringe into fluoride tubes for glucose determination and the remainder was transported under refrigeration to the laboratory for centrifugation and determination of NEFA level according to the method of Dole (1). The analysis was done as rapidly as possible after withdrawal. In addition to analyses for sugar and NEFA, serum cholesterol was determined by the method of Abell, Levy, Brodie and Kendall (7) and triglycerides were determined by the method of Van Handel and Zilversmit (8). Blood sugar was done by the method of Somogyi $(9,10)$.

The insulin used for the study was hyperglycemic factor-free crystalline zinc insulin freshly prepared in saline for each experiment. The time required for injection was less than 10 seconds.

Six subjects were studied, observations being made on six injected limbs and six control limbs. All studies were carried out on lower extremities except for one control limb (Subject P). In this instance the arm was used instead of the leg because of difficulty in obtaining blood from the femoral vein.

\section{RESULTS}

The results are listed in Tables I through V. The changes to be emphasized are as follows.

\section{Arterial NEFA level}

The arterial level of NEFA at the control period ranged from 339 to $915 \mu$ Moles per L., all wtihin the accepted normal range. The mean arterial level of NEFA was significantly decreased after insulin injection (Table I). Although the relaxation of the subjects after the placement of the needles cannot be ruled out as a cause of the drop in this study $(11,12)$, such a drop in arterial NEFA has not been seen in other subjects receiving arterial injections of materials not affecting NEFA release.

\section{A-V NEFA difference}

Table II shows, for each subject, the A-V NEFA differences, both before and after insulin, 
TABLE I

Arterial nonesterified fatty acid level (micromoles per liter): Change after insulin

\begin{tabular}{|c|c|c|c|c|c|}
\hline Subject & $\begin{array}{l}\text { Control } \\
\text { period }\end{array}$ & $\begin{array}{c}10 \mathrm{~min} . \\
\text { after } \\
\text { insulin }\end{array}$ & $\begin{array}{l}\text { Change } \\
\text { during } \\
10 \mathrm{~min} .\end{array}$ & $\begin{array}{c}20 \text { min. } \\
\text { after } \\
\text { insulin }\end{array}$ & $\begin{array}{l}\text { Change } \\
\text { during } \\
\text { entire } \\
20 \mathrm{~min} .\end{array}$ \\
\hline $\begin{array}{l}\text { N } \\
\text { P } \\
\text { E } \\
\text { L } \\
\text { McI } \\
\text { McD }\end{array}$ & $\begin{array}{l}703 \\
876 \\
339 \\
354 \\
485 \\
915\end{array}$ & $\begin{array}{l}676 \\
769 \\
275 \\
306 \\
446 \\
775\end{array}$ & $\begin{array}{r}-27 \\
-107 \\
-64 \\
-48 \\
-39 \\
-140\end{array}$ & $\begin{array}{l}525 \\
504 \\
206 \\
306 \\
451 \\
648\end{array}$ & $\begin{array}{r}-178 \\
-372 \\
-133 \\
-48 \\
-34 \\
-267\end{array}$ \\
\hline Mean & 612 & 541 & -71 & 440 & -172 \\
\hline \multicolumn{2}{|c|}{ "t $t$ " value } & \multicolumn{3}{|c|}{3.96} & 3.23 \\
\hline \multicolumn{2}{|l|}{ p } & \multicolumn{3}{|c|}{$<0.02$} & $<0.05$ \\
\hline
\end{tabular}

for both the injected and noninjected limbs. In the injected leg, the initially negative A-V NEFA difference was narrowed at 10 minutes and, in four cases, reversed at 20 minutes. Changes in the $\mathrm{A}-\mathrm{V}$ differences from the control period were large and uniform enough to be statistically significant ( $p$ being less than 0.05 at 10 minutes and less than 0.01 at 20 minutes after insulin injection). The noninjected limb showed no significant change in $\mathrm{A}-\mathrm{V}$ differences.

Table III provides two further evidences that, regarding NEFA, insulin acted chiefly in the injected limb. Twenty minutes after insulin, the A-V NEFA change was significantly ${ }^{1}$ different in the two limbs. Further, during the first $10 \mathrm{~min}$ -

1 In testing significance, the A-V difference across the control limb was subtracted for each subject from that for the injected limb, and the resulting number (i.e., a difference of a difference) was tested against the null hypothesis. utes, the change in A-V difference from the control condition was also significantly ${ }^{2}$ different.

\section{Glucose}

The A-V glucose difference changes were as described by Bell and Burns (6) : a widening in the injected limb, a narrowing in the uninjected limb (Tables IV and V).

\section{Triglyceride and cholesterol}

There was no significant alteration in triglyceride or cholesterol levels during the course of the study.

\section{DISCUSSION}

The tremendous responsiveness of the peripheral tissues of the leg to small doses of insulin is well shown in these studies. They confirm the reports of Bell and Burns (6) that insulin injected in small quantity into the artery supplying a single limb has a major effect on glucose uptake in this limb as compared to the remainder of the body; they show in addition that these effects extend to the NEFA as well as to glucose. It is felt that these studies show a primary effect of insulin on peripheral tissues, presumably adipose tissues, in regulating the level of NEFA as well as in regulation of blood glucose. The exit of NEFA from adipose tissues of the injected limb is reduced in contrast to the exit of NEFA from the uninjected limb.

It should be noted that at 20 minutes after in-

2 The change in A-V difference from the control condition was similarly compared between the two limbs. In effect, the noninjected limb was used as an individual control.

TABLE II

Arteriovenous ( $A-V)$ nonesterified fatty acid difference (micromoles per liter): Individual values

\begin{tabular}{|c|c|c|c|c|c|c|}
\hline \multirow[b]{2}{*}{ Subject } & \multicolumn{2}{|c|}{ Control period } & \multicolumn{2}{|c|}{$10 \mathrm{~min}$. after insulin } & \multicolumn{2}{|c|}{$20 \mathrm{~min}$. after insulin } \\
\hline & $\begin{array}{c}\text { Injected } \\
\text { limb }\end{array}$ & $\underset{\substack{\text { Noninjected } \\
\text { limb }}}{ }$ & $\begin{array}{c}\text { Injected } \\
\text { limb }\end{array}$ & $\begin{array}{c}\text { Noninjected } \\
\text { limb }\end{array}$ & $\begin{array}{c}\text { Injected } \\
\text { limb }\end{array}$ & $\begin{array}{c}\text { Noninjected } \\
\text { limb }\end{array}$ \\
\hline $\begin{array}{l}\mathrm{N} \\
\mathrm{P} \\
\mathrm{E} \\
\mathrm{L} \\
\mathrm{McI} \\
\mathrm{McD}\end{array}$ & $\begin{array}{r}-163 \\
-71 \\
-73 \\
-64 \\
-40 \\
-231\end{array}$ & $\begin{array}{c}-190 \\
+48^{*} \\
-73 \\
-84 \\
-21 \\
+3\end{array}$ & $\begin{array}{l}-69 \\
+15 \\
+25 \\
-53 \\
-46 \\
-65\end{array}$ & $\begin{array}{c}-186 \\
-77^{*} \\
-51 \\
-119 \\
-25 \\
-15\end{array}$ & $\begin{array}{r}+44 \\
+57 \\
-17 \\
+21 \\
-21 \\
+100\end{array}$ & $\begin{array}{l}-90 \\
-52 * \\
-42 \\
-60 \\
-2 \\
-58\end{array}$ \\
\hline Mean & -107.00 & -52.83 & -32.17 & -78.83 & +30.67 & -50.67 \\
\hline
\end{tabular}

* Brachial vein. 
TABLE III

Arteriovenous ( $A-V$ ) nonesterified fatty acid difference (micromoles per liter): Comparison of change in injected and noninjected limbs

\begin{tabular}{|c|c|c|c|c|c|}
\hline & \multirow{2}{*}{$\frac{\text { Control period }}{\begin{array}{c}\text { A-V } \\
\text { difference }\end{array}}$} & \multicolumn{2}{|c|}{$10 \mathrm{~min}$. after insulin } & \multicolumn{2}{|c|}{$20 \mathrm{~min}$. after insulin } \\
\hline & & $\begin{array}{c}\text { A-V } \\
\text { difference }\end{array}$ & $\begin{array}{l}\text { Change from } \\
\text { control level }\end{array}$ & $\begin{array}{c}\text { A-V } \\
\text { difference }\end{array}$ & $\begin{array}{l}\text { Change from } \\
\text { control level }\end{array}$ \\
\hline $\begin{array}{l}\text { Injected limb } \\
\text { Noninjected limb } \\
\text { Difference } \\
\text { " } t \text { " value }\end{array}$ & $\begin{array}{r}-107.0 \\
-52.82 \\
-54.18 \\
1.75\end{array}$ & $\begin{array}{r}-32.17 \\
-78.83 \\
+46.66 \\
1.50\end{array}$ & $\begin{array}{r}+74.83 \\
-26.01 \\
+100.84 \\
3.02\end{array}$ & $\begin{array}{r}+30.67 \\
-50.67 \\
+81.33 \\
2.62\end{array}$ & $\begin{array}{r}+137.67 \\
+2.15 \\
+135.52 \\
2.22\end{array}$ \\
\hline & $\begin{array}{c}\text { (Not signif- } \\
\text { icant) }\end{array}$ & $\begin{array}{l}\text { (Not signif- } \\
\text { icant) }\end{array}$ & $(p<0.05)$ & $(\mathrm{p}<0.05)$ & $\begin{array}{c}\text { (Not signif- } \\
\text { icant) }\end{array}$ \\
\hline
\end{tabular}

jection of insulin, the mean arterial level of NEFA usually exceeded the mean venous level of NEFA in the injected limb. This is not felt to represent an increased uptake of NEFA but a suppressed release of it which allowed the utilization of NEFA to exert a predominant effect on the venous level.

\section{SUM MARY}

1. The tissues of the leg exhibited extreme responsiveness to injection of small doses of insulin.

2. Arterial nonesterified fatty acid (NEFA) level dropped significantly within 20 minutes after intra-arterial injection of small doses of insulin.

3. The arteriovenous (A-V) NEFA difference in the injected limb changed significantly after insulin injection, from a negative $A-V$ difference to a frequently positive $\mathrm{A}-\mathrm{V}$ difference.

4. The A-V NEFA difference in the control limb did not change after insulin injection.

TABLE IV

Arterial glucose (milligrams per 100 milliliters): Change after insulin

\begin{tabular}{lccc}
\hline \hline Subject & $\begin{array}{c}\text { Control } \\
\text { period }\end{array}$ & $\begin{array}{c}10 \mathrm{~min} . \\
\text { after } \\
\text { insulin }\end{array}$ & $\begin{array}{c}20 \mathrm{~min} . \\
\text { after } \\
\text { insulin }\end{array}$ \\
\hline $\mathrm{N}$ & 84.2 & 78.0 & 74.0 \\
$\mathrm{P}$ & 77.8 & 74.0 & 72.2 \\
$\mathrm{E}$ & 73.7 & 59.8 & 49.1 \\
$\mathrm{~L}$ & 82.2 & 82.8 & 76.8 \\
McI & 96.0 & 83.9 & 75.1 \\
McD & 96.2 & 86.8 & 75.4 \\
Mean & 85.0 & 77.7 & 70.4 \\
\hline
\end{tabular}

Mean change from control to $10 \mathrm{~min}$. after insulin $=(-) 7.30(" \mathrm{t} "=3.213, \mathrm{p}<0.05)$.

Mean change from 10 to $20 \mathrm{~min}$. after insulin $=(-) 7.28(" t "=5.009, p<0.01)$.
5. At 20 minutes after insulin injection the change in $\mathrm{A}-\mathrm{V}$ NEFA difference in the injected limb was significantly different from that of the control limb and demonstrates a distinct action in the injected limb apart from the rest of the body.

TABLE V

Glucose arteriovenous ( $A-V$ ) difference (milligrams per 100 milliliters): Individual values

\begin{tabular}{|c|c|c|c|c|c|c|}
\hline \multirow[b]{2}{*}{ Subject } & \multicolumn{2}{|c|}{ Control period } & \multicolumn{2}{|c|}{10 min. after } & \multicolumn{2}{|c|}{20 min. after } \\
\hline & $\begin{array}{c}\text { Injected } \\
\text { limb }\end{array}$ & $\begin{array}{l}\text { Nonin- } \\
\text { jected } \\
\text { limb }\end{array}$ & $\begin{array}{c}\text { Injected } \\
\text { limb }\end{array}$ & $\begin{array}{l}\text { Nonin- } \\
\text { jected } \\
\text { limb }\end{array}$ & $\begin{array}{c}\text { Injected } \\
\text { limb }\end{array}$ & $\begin{array}{l}\text { Nonin- } \\
\text { jected } \\
\text { limb }\end{array}$ \\
\hline $\begin{array}{l}\mathrm{N} \\
\mathrm{P} \\
\mathrm{E} \\
\mathrm{L} \\
\mathrm{McI} \\
\mathrm{McD} \\
\text { Mean }\end{array}$ & $\begin{array}{c}+3.4 \\
+4.9 \\
+0.7 \\
+2.1 \\
0.0 \\
+4.4 \\
+2.58\end{array}$ & $\begin{array}{l}+4.2 \\
+3.8^{*} \\
+4.3 \\
+0.7 \\
+0.6 \\
+3.6 \\
+2.87\end{array}$ & $\begin{array}{c}+4.2 \\
+7.5 \\
+10.9 \\
+2.8 \\
+5.0 \\
+13.1 \\
+7.25\end{array}$ & $\begin{array}{l}+1.4 \\
+0.2^{*} \\
-0.5 \\
+3.1 \\
-1.0 \\
-0.9 \\
+0.38\end{array}$ & $\begin{array}{c}+7.0 \\
+12.9 \\
+9.2 \\
+13.6 \\
+7.9 \\
+14.6 \\
+10.87\end{array}$ & $\begin{array}{l}+2.3 \\
+3.1 * \\
+2.3 \\
+1.0 \\
-2.4 \\
-0.5 \\
+0.97\end{array}$ \\
\hline \multicolumn{7}{|c|}{$\begin{array}{l}\text { Mean dif- } \\
\text { ference }-0.31\end{array}$} \\
\hline \multicolumn{3}{|c|}{$\begin{array}{l}\text { " } t "=0.41 \\
\text { (Not significant) }\end{array}$} & \multicolumn{2}{|c|}{$\begin{array}{l}(" \mathrm{t} "=3.18, \\
\mathrm{p}<0.05)\end{array}$} & \multicolumn{2}{|c|}{$\begin{array}{l}(" \mathrm{t} "=8.52 \\
\mathrm{p}<0.01)\end{array}$} \\
\hline
\end{tabular}

* Brachial vein.

6. The observed changes are considered to reflect a local suppression by insulin of NEFA release. This effect accompanies a local increase in glucose uptake, as was described by Bell and Burns (6).

\section{REFERENCES}

1. Dole, V. P. A relation between non-esterified fatty acids in plasma and the metabolism of glucose. J. clin. Invest. 1956, 35, 150.

2. Gordon, R. S., Jr., and Cherkes, A. Unesterified fatty acid in human blood plasma. J. clin. Invest. 1956, 35, 206. 
3. Bierman, E. L., Schwartz, I. L., and Dole, V. P. Action of insulin on release of fatty acids from tissue stores. Amer. J. Physiol. 1957, 191, 359.

4. Gordon, R. S., Jr., and Cherkes, A. Production of unesterified fatty acids from isolated rat adipose tissue incubated in vitro. Proc. Soc. exp. Biol. (N. Y.) 1958, 97, 150.

5. Gordon, R. S., Jr. Unesterified fatty acid in human blood plasma. II. The transport function of unesterified fatty acid. J. clin. Invest. 1957, 36, 810.

6. Bell, D. M., and Burns, T. Effect of femoral A-V glucose difference of insulin injected into an antecubital vein and into a femoral artery. J. clin. Invest. 1952, 31, 717.

7. Abell, L. L., Levy, B. B., Brodie, B. B., and Kendall, F. E. A simplified method for the estimation of total cholesterol in serum and demonstration of its specificity. J. biol. Chem. 1952, 195, 357.

8. Van Handel, E., and Zilversmit, D. B. Micromethod for the direct determination of serum triglycerides. J. Lab. clin. Med. 1957, 50, 152.

9. Somogyi, M. A new reagent for the determination of sugars. J. biol. Chem. 1945, 160, 61.

10. Somogyi, M. Determination of blood sugar. J. biol. Chem. 1945, 160, 69.

11. Fredrickson, D. S., and Gordon, R. S., Jr. Transport of fatty acids. Physiol. Rev. 1958, 38, 585.

12. Bogdonoff, M. D., Estes, E. H., Jr., and Trout, D. Acute effect of psychologic stimuli upon plasma non-esterified fatty acid level. Proc. Soc. exp. Biol. (N. Y.) 1959, 100, 503. 